\title{
ENTOLOMA MOUGEOTIII (Fr.) Hesler: A NEW RECORD FOR TURKISH MYCOTA FROM KÖYCEĞİZ PROVINCE
}

\author{
Gizem Nur DEMIREL* \\ Department of Biology, Faculty of Science, Mugla Sitki Kocman University, Turkey, gizemnurdemirel@gmail.com \\ (iD) https://orcid.org/0000-0002-7857-4210) \\ Hakan ALLI
}

Department of Biology, Faculty of Science, Mugla Sitki Kocman University, Turkey, hakanalli@gmail.com

(iD) https://orcid.org/0000-0001-8781-7029)

Anara BABAYEVA

Department of Biology, Faculty of Science, Mugla Sitki Kocman University, Turkey, anara.babazade@gmail.com

(iD) https://orcid.org/0000-0001-6797-3366)
Esra DİBEK

Department of Biology, Faculty of Science, Mugla Sitki Kocman University, Turkey, esradibek@gmail.com

(iD) https://orcid.org/0000-0002-8110-5466)

Bekir ÇÖL

Department of Biology, Faculty of Science, Mugla Sitki Kocman University, Turkey, bekircol@gmail.com

(iD) https://orcid.org/0000-0001-8997-4116)

Received: 08.07.2019, Accepted: 26.09.2019

Research Article

*Corresponding author

DOI: $10.22531 /$ muglajsci.589090

\begin{abstract}
In this study, Entoloma mougeotii (Fr.) Hesler is presented as a new record for the first time from Turkey. Within the scope of study, both morphological features were determined and ITS gene of this species was sequenced. Photographs, location, habitat and ecological characteristics of this species and a phylogenetic tree based on its ITS (internal transcribed spacer region of rDNA) gene region are obtained and taxonomic details regarding the species are discussed.

Keywords: Entoloma mougeotii, ITS, new record, Köyceğiz, phylogeny, Turkey

\section{ENTOLOMA MOUGEOTİ̈ (Fr.) Hesler: KÖYCEĞiZ YÖRESINDEN TÜRKIYYE MİKOTASI İÇIN BİR YENI KAYIT}

\begin{abstract}
Özet türe ait taksonomik özellikler verilmiştir.

Cite

\section{Introduction}

Entoloma species, usually grown on the soil, the pileus with various colors is tapered, spherical, concave or straight. Its surface is generally fibrous or flat. Lamellae are free with different density and in a wide variety of colors. Stipe is usually fibrous and of various colors; may be in the center in some species of the genus, partly out of the center or laterally. Basidia generally have 4 spores and cystidia are found in some species. Basidiospores are angular and generally thick. The
\end{abstract}

Bu çalışmada, Entoloma mougeotii (Fr.) Hesler mantar türü Türkiye'den ilk kez yeni kayıt olarak sunulmuştur. Çalışma kapsamında bu türün hem morfolojik özellikleri belirlenmiş, hem de ITS gen dizisi verileri elde edilmiştir. Bu türe ait fotoğraf, lokasyon, habitat ve ekolojik özelliklerinin yanı sıra, ITS gen dizisine dayalı filogenetik ağacı oluşturulmuş ve

Anahtar Kelimeler: Entoloma mougeotii, ITS, yeni kayıt, Köyceğiz, filogeni, Türkiye

Demirel, G.N., Allı, H., Babayeva, A., Dibek, E., Çöl, B., (2019). “Entoloma Mougeotii (Fr.) Hesler: A New Record For Turkish

Mycota From Köyceğiz Province”, Mugla Journal of Science and Technology, 5(2), 77-80.

members of the genus are saprophyte or mycorrhizal, rarely live as parasite $[1,2,3]$.

Entoloma P. Kumm. genus has a wide distribution area around the world and contains 2142 species [4]. There are 50 species belonging to this genus in Turkey [5]. In recent years, various new records related to the genus have been identified with the aim of molecular studies conducted to determine the macromycota of our country $[6,7,8,9,10,11,12,13,14]$. The aim of this report is to introduce Entoloma mougeotii (Fr.) Hesler as a new record for Turkey based on the results of 
molecular phylogenetic analyses and morphological investigation.

\section{Material-Methods}

\subsection{Morphological Study}

The fungal sample which was analyzed within the scope of the study, was collected from Muğla/Köyceğiz region in 2018. The color, smell and habitat characteristics of the specimen were determined in the field and the land conditions were recorded and photographed.

The collected specimen has been transported to the laboratory environment and the specimen in the laboratory was dried under suitable conditions, bagged with the land number and deposited in the Fungarium of Muğla Sitkı Koçman University. The spore color, shape and dimensions of the specimen were determined by a light microscope using the preparation prepared with distilled water. The macroscopic and microscopic features of the specimens were examined but some difficulties were encountered in the identification of the species. Therefore the molecular studies were performed in addition to the classical methods.

\subsection{Molecular Study}

For genomic DNA isolation of the specimen, the Qiagen DNeasy Plant Mini Kit was used and DNA isolation was performed. From the obtained genomic DNA, ITS gene region was amplified by PCR. For this, ITS1F and ITS4 primers were used. PCR products purified by the Fermentas GeneJET Gel Extraction Kit was sequenced. Using BioEdit Sequence Alignment Editor program, the quality of sequence peaks was evaluated based on the chromotograms. The resulting ITS gene sequence was analyzed via BlastN to obtain the closest nucleotide sequences in GenBank. Then, the resulting sequence was used to construct a phylogenetic tree using MEGA 7.0.26 program [15]. The results obtained from the phylogenetic analysis and systematic data were evaluated and the sample was re-examined for species identification.

\section{Results}

\subsection{Macroscopic and Microscopic Characters GenBank No: MK972939.1 of Entoloma mougeotii (Fr.) Hesler}

Pileus, 2-4 cm, convex, umbilicate, entirely minutely tomentose-finely scaly, not hygrophanous, not translucently striate, dark violaceous-black or violaceous-grey (Figure 1b). Lamellae, adnate, emarginate or with decurrent tooth, white or pale cream, then pink (Figure 1c). Stipe, $2-5 \mathrm{~cm}$, cylindrical, violaceous grey, fibrillose (Figure 1a). Basidiospores, 9-11,5 x 6-8 $\mu \mathrm{m}$, heterodiametrical, 5-8 angled in sideview, pink colored (Figure 2a). Basidia, 27 - $48 \times 9-14$ $\mu \mathrm{m}, 4$ spored (Figure 2b). Cheilocystidia, $16-60 \times 7-$ $17 \mu \mathrm{m}$, cylindrical to slenderly clavate (Figure 2c).

Habitat: In grassland, preferably on calcareous soil; summer to autumn.
Material examined: Toparlar neighborhood, Liquidambar orientalis Mill. forest, $36^{\circ} 59^{\prime} \mathrm{N}-28^{\circ} 38^{\prime} \mathrm{E}, 15$ m, 23.12.2017, GNZ 190.

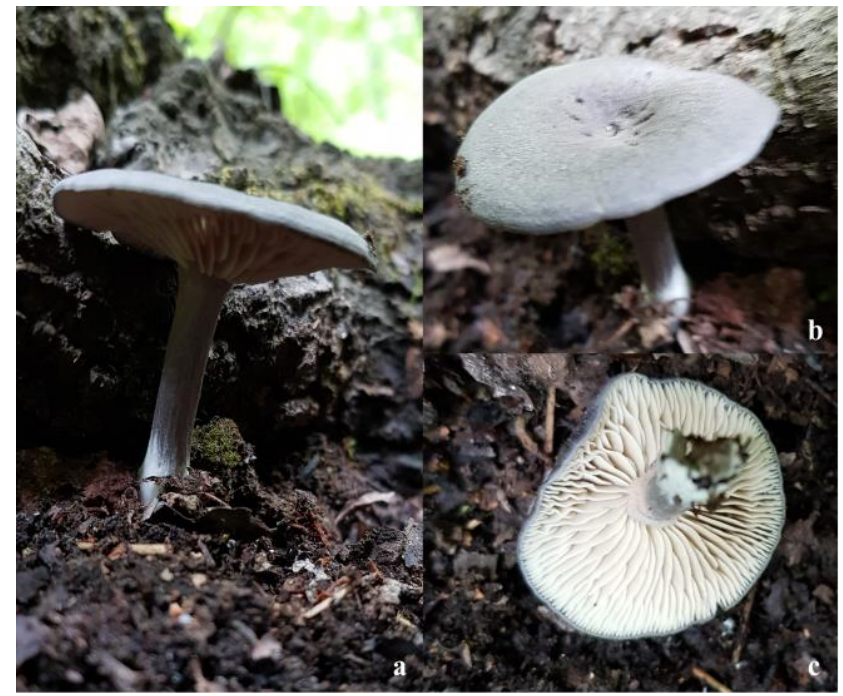

Figure1. Macroscopic structures of Entoloma mougeotii; a. Stipe, b. Pileus, c. Lamellae

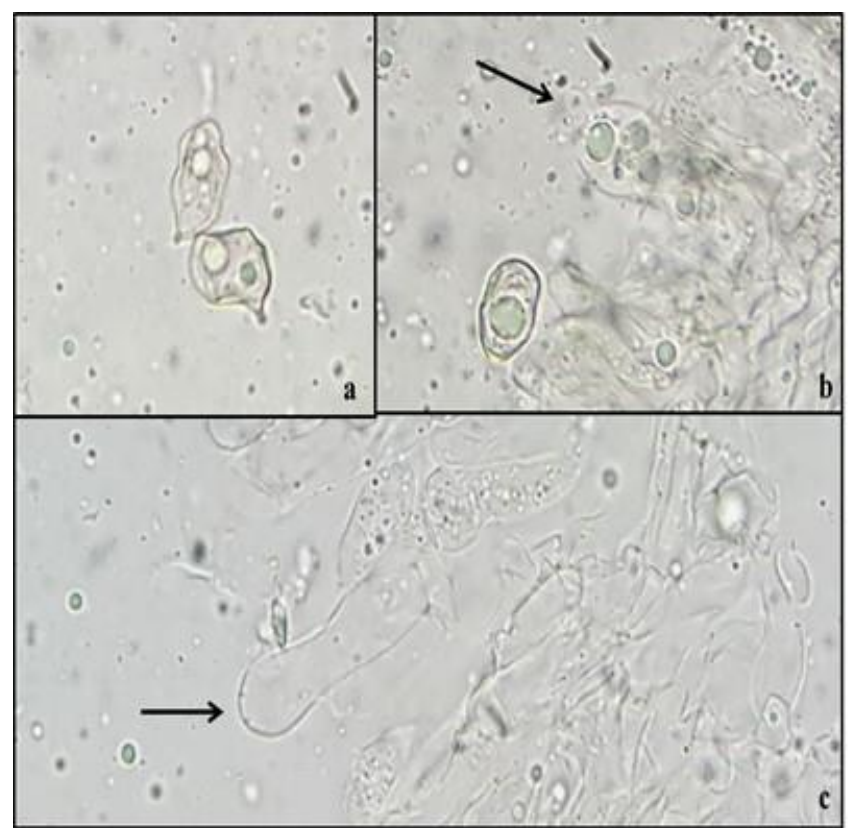

Figure2. Microscopic structures of Entoloma mougeotii; a. Basidiospores, b. Basidia, c. Cheilocystidia

\subsection{Molecular Results}

Genomic DNA isolation was successfully isolated (Figure 3a). PCR was done using ITS1F and ITS4 primers (Figure $3 \mathrm{~b}$ ) and the PCR product was purified (Figure 3c) and sequenced (Macrogen, the Netherlands). 

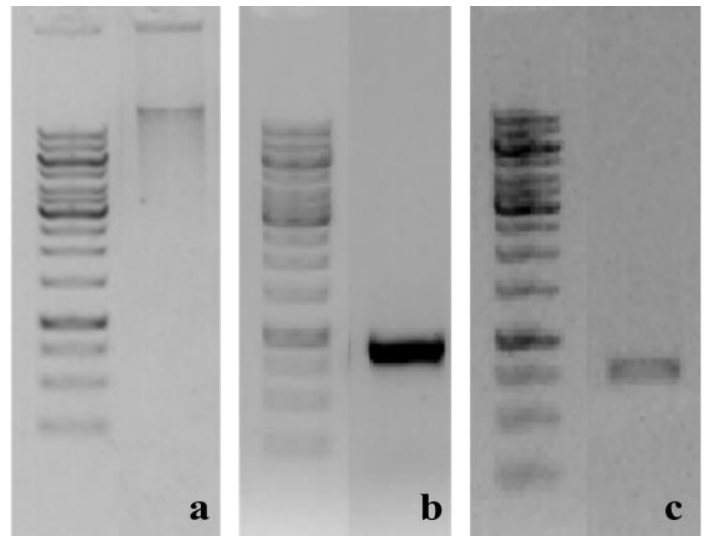

Figure 3. Agarose gel images of genomic DNA and PCR product. a. Genomic DNA (loaded $3 \mu \mathrm{l}$ ); b. PCR product

(loaded $8 \mu \mathrm{l}$ ); c. PCR purification (loaded $2 \mu \mathrm{l}$ )

The sequence of the species was analyzed with BlastN. Sequence analysis revealed that this species was Entoloma mougeotii. For phylogenetic analyzes, ITS gene region sequences of some Entoloma species were downloaded from the GenBank (Table 1). Then, the phylogenetic tree was constructed using Mega 7 program (Figure 4).

Table1.Taxa and GenBank accession numbers for specimens used in the present study

\begin{tabular}{ccc}
\hline Taxon & Location & $\begin{array}{c}\text { GenBank } \\
\text { accession } \\
\text { numbers }\end{array}$ \\
\hline Entoloma mougeotii & Russia & KC898446.1 \\
Entoloma fuscosquamosum & USA & KY777405.1 \\
Entoloma griseocyaneum & Canada & KY706188.1 \\
Entoloma caesiocinctum & UK & MF977967.1 \\
Entoloma serrulatum & Russia & KC898447.1 \\
Entoloma undatum & Spain & KJ001410.1 \\
Entoloma undatum & Russia & MF476910.1 \\
Entoloma cyanostipitum & China & KY972700.1 \\
Entoloma subserrulatum & Canada & KY706167.1 \\
Entoloma subclitocyboides & China & JQ320112.1 \\
Entoloma cuspidiferum & UK & EU784218.1 \\
Entoloma albogriseum & Canada & KJ705171.1 \\
\hline
\end{tabular}

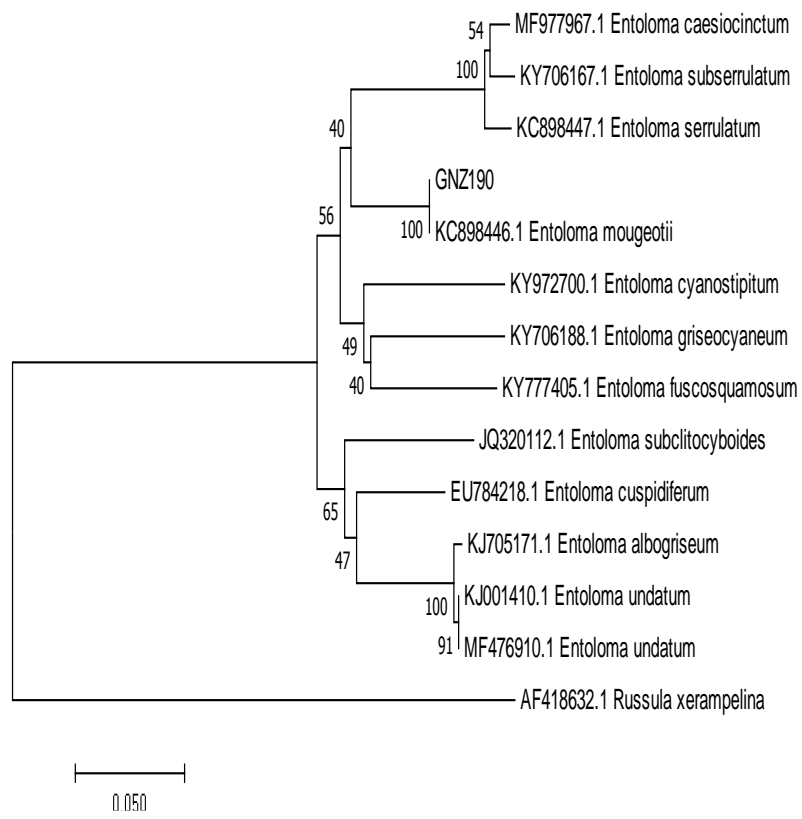

Figure 4. Neigbour-Joining phylogenetic tree of the new record of Entoloma mougeotii(GNZ190) and related species selected from the GenBank.

\section{Conclusion}

As a result, the identification of Entoloma mougeotii (Fr.) Hesler was successfully done using molecular and morphological approaches and this species is presented as a new record for Turkey $[5,16]$. In this study, we showed that sequencing of the ITS gene region helped in species identification. Also, this study confirmed that molecular studies are sometimes necessary to correctly and quickly identify the samples that are otherwise difficult to decipher by the classical methods. ITS gene sequence analysis once again proved to be efficient in the determination of the Entoloma species and we suggest the use of ITS gene as a barcode gene for this genus and others in subsequent studies aimed to find new records and novel species.

\section{Acknowledgment}

We would like to thank Muğla Sitkı Koçman University BAP division (project no 17/105).

\section{References}

[1] Noordeloos, M.E., "Fungi Europaei: Entoloma (in Italian)", Giovanna Biella, Saronno, Italy, 1992.

[2] Knudsen, H. and Vesterholt, J., "Funga Nordica", Nordsvamp, Copenhagen, 2008.

[3] Sesli, E., "Entoloma subserrulatum (Peck) Hesler (Entolomataceae): Türkiye mikotası için yeni bir kayıt", Bağbahçe Bilim Dergisi, 4(1):13-16, 2017.

[4] Kirk, P. Index Fungorum, Website: http:// www.speciesfungorum.org; accessed 04.01.2019, 2011.

[5] Solak, M.H., Işıloğlu, M., Kalmış, E. and Allı, H., "Macrofungi of Turkey, Checklist Vol. 2", İzmir Üniversiteliler Ofset, 2015. 
[6] Akata, I., Doğan, H. H., Öztürk, Ö. and Bozok, F., "Suillus lakei, An Interesting Record for Turkish Mycobiota", Mantar Dergisi, 9 (2),110-116, 2018.

[7] Chang Sun Kim., Jong Won Jo., Young-Nam Kwag., Junsang Oh., Bhushan Shrestha., Gi-Ho Sung and Sang-Kuk Han., "Two Newly Recorded Entoloma Species, E. eugenei and E. subaraneosum, in Korea." Kor. J. Mycol. 43(2): 118-124, 2015.

[8] Co-David, D., Langeveld, D., Noordeloos, M.E., "Molecular phylogeny and spore evolution of Entolomataceae." Persoonia 23: 147-176, 2009.

[9] Çöl, B., Şen, İ., Allı, H., Has, G. and Tırpan, E.,"Bazı Inocybe (Fr.) Fr. Taksonlarının Morfolojik ve Moleküler Yöntemlerle Karakterizasyonu"Süleyman Demirel Üniversitesi Fen Bilimleri Enstitüsü Dergisi 21(2): 659-665, 2017.

[10] Doğan, H.H., Bozok, F. and Taşkın, H., "A new species of Barssia (Ascomycota, Helvellaceae) from Turkey"Turkish Journal of Botany, 42: 636-643, 2018.

[11] Doğan, H.H. and Allı, H., "A new genus (Balsamia) addition for Turkish mycota". Mantar Dergisi, 10 (1), 23-25, 2019.

[12] Kaya, A. and Uzun, Y.,"Leucocoprinus cepistipes, A New Coprinoid Species Record for Turkish Macromycota"Süleyman Demirel Üniversitesi Fen Bilimleri Enstitüsü Dergisi, 22 (1), 60-63, 2018.

[13] Sesli, E. and Topcu, Sesli A., "Entoloma majaloides (Entolomataceae): Türkiye Mikotası İçin Yeni Bir Kaylt", Mantar dergisi, 8(2):85-89, 2017.

[14] Şen, İ., Allı, H. and Çöl, B., "Tricholoma bonii, A New Record for Turkish Mycota and Notes on its Taxonomic Status Based on Morphological and Molecular Evidence" Turkish Journal of Life Sciences, 3(1): 200-204, 2018.

[15] Kumar, S., Stecher, G. and Tamura, K., "MEGA7: Molecular Evolutionary Genetics Analysis Version 7.0 for Bigger Datasets", Molecular Biology and Evolution, 33(7): 1870-1874, 2016.
[16] Sesli, E. and Denchev, C. M., "Checklists of the Myxomycetes, Larger Ascomycetes, and Larger Basidiomycetes in Turkey", 6 th., Mycotaxon Checklists Online, 1-136, 2014. 